University of Nebraska - Lincoln

DigitalCommons@University of Nebraska - Lincoln

Textile Society of America Symposium

Proceedings

2020

\title{
Ethnoarchaeology of the Textile Chaîne Operatoire. Searching for Evidence of Prehispanic Textile Production in Domestic Sites
}

\author{
Bárbara Cases \\ Universidad de Tarapacá, Chile, barbara_cases@yahoo.es
}

Follow this and additional works at: https://digitalcommons.unl.edu/tsaconf

Digitalrt of the Art and Materials Conservation Commons, Art Practice Commons, Fashion Design

Commens, Fiber, Textile, and Weaving Arts Commons, Fine Arts Commons, and the Museum Studies Netwerkns

Logo

Cases, Bárbara, "Ethnoarchaeology of the Textile Chaîne Operatoire. Searching for Evidence of Prehispanic Textile Production in Domestic Sites" (2020). Textile Society of America Symposium Proceedings. 1167.

https://digitalcommons.unl.edu/tsaconf/1167

This Article is brought to you for free and open access by the Textile Society of America at DigitalCommons@University of Nebraska - Lincoln. It has been accepted for inclusion in Textile Society of America Symposium Proceedings by an authorized administrator of DigitalCommons@University of Nebraska - Lincoln. 


\title{
Ethnoarchaeology of the Textile Chaîne Operatoire. Searching for Evidence of Prehispanic Textile Production in Domestic Sites
}

\author{
barbara_cases@yahoo.es
}

\section{Introduction}

This article presents the principal aspects of research designed to develop an analytic model for approaching textile production in pre-Hispanic habitation sites and to test it in the analysis of a domestic textile assemblage in the far north of Chile (Figure 1). ${ }^{1}$

Our interest in taking up this task grew from noting a marked difference between the current development of analytic approaches to archaeological textiles found in cemeteries of northern Chile, and to those found in residential sites. ${ }^{2}$ This is due principally to the differences in textile conservation in these two types of site. Those which form part of a funerary context and its offerings tend to be found in a more complete state and with a better level of conservation than those found in midden deposits and domestic contexts, which are therefore more difficult to analyze and interpret. Nonetheless, they have great potential for addressing production practices, daily use and social functions of textiles found within the very spaces in which they may have been created and used. Paradoxically, based on the funerary textiles, arguments have been developed to "characterize" both their use in life and the textile production process, based on analogic reasoning. ${ }^{3}$

We have lacked methodological tools for addressing the elusive topic of pre-Hispanic textile production, and moreover there are few systematic studies of contemporary weavings that include detailed technical description. The information available at the time this research was begun ${ }^{4}$ did

\footnotetext{
${ }^{1}$ Bárbara Cases, Etnoarqueología y Tecnología de las Bolsas a la Producción Textil Prehispánica. Un caso de estudio en Huancarane (Período Intermedio Tardío, Valle de Camarones). PhD dissertation, Departamento de Antropología de la Universidad de Tarapacá e Instituto de Investigaciones Arqueológicas, Universidad Católica del Norte (Chile, 2017).

${ }^{2}$ Hans Niemeyer and Virgilio Schiapaccasse, "Aportes al conocimiento del Período Tardío del extremo norte de Chile: Análisis del sector de Huancarane del valle de Camarones." Chungara 7 (1981), 3-103; Iván Muñoz "Ocupación del espacio doméstico y áreas de actividad generadas en el asentamiento prehispánico de San Lorenzo." Diálogo Andino 24 (2004), 53-97; Carolina Agüero and Donley-Zori, "Otro quipu encontrado al sur de Arica." Boletín de la Sociedad Chilena de Arqueología 40 (2007), 21-28; Calogero M. Santoro, Late prehistoric regional interaction and social change in a coastal valley of northern Chile. Ph.D. Dissertation, Department of Anthropology, University of Pittsburgh, Pittsburgh (1995).

${ }^{3}$ Carolina Agüero, Mauricio Uribe, Patricia Ayala and Bárbara Cases, "Una aproximación arqueológica a la etnicidad y el rol de los textiles en la construcción de la identidad cultural en los cementerios de Quillagua (Norte de Chile)." Gaceta Arqueológica Andina 25 (1999), 167-197; Bárbara Cases, "Las bolsas de Quillagua y su relación con el tráfico de caravanas." Werken 4 (2003), 5-24; Helena Horta and Carolina Agüero "Definición de chuspa: textil de uso ritual durante el Período Intermedio Tardío, en la zona arqueológica de Arica". In Actas del XIV Congreso Nacional de Arqueología Chilena, (Museo Regional de Atacama, Copiapó. 2000), 45-82; Helena Horta and Carolina Agüero, "Estilo, iconografía y función de las inkuñas prehispánicas del norte de Chile durante el Período Intermedio Tardío (1.000-1.470 D.C.)." Chungara, Revista de Antropología Chilena 41(2) (2009), 183-227; Helena Horta, El señorío Arica y Los Reinos Altiplánicos (1000-1450 DC). Complementariedad ecológica y multietnicidad durante los siglos pre-conquista en el norte de Chile. (Ocho Libros Editores, 2015).

${ }^{4}$ This doctoral research project was initiated in 2008.
} 
not include fine-grained data on the textile production process which would permit development of a model based on analogy. For this reason, we decided to document in detail the activities that form part of processes of textile production and use carried out today by the weavers of northern Chile, from an archaeological and technological viewpoint. In other words, we would consider actions, objects, gestures, forms of knowledge, participants, duration, time of the year, the materials discarded as a result of these activities, the tools used and the locations where they took place, as well as the persons who were present.

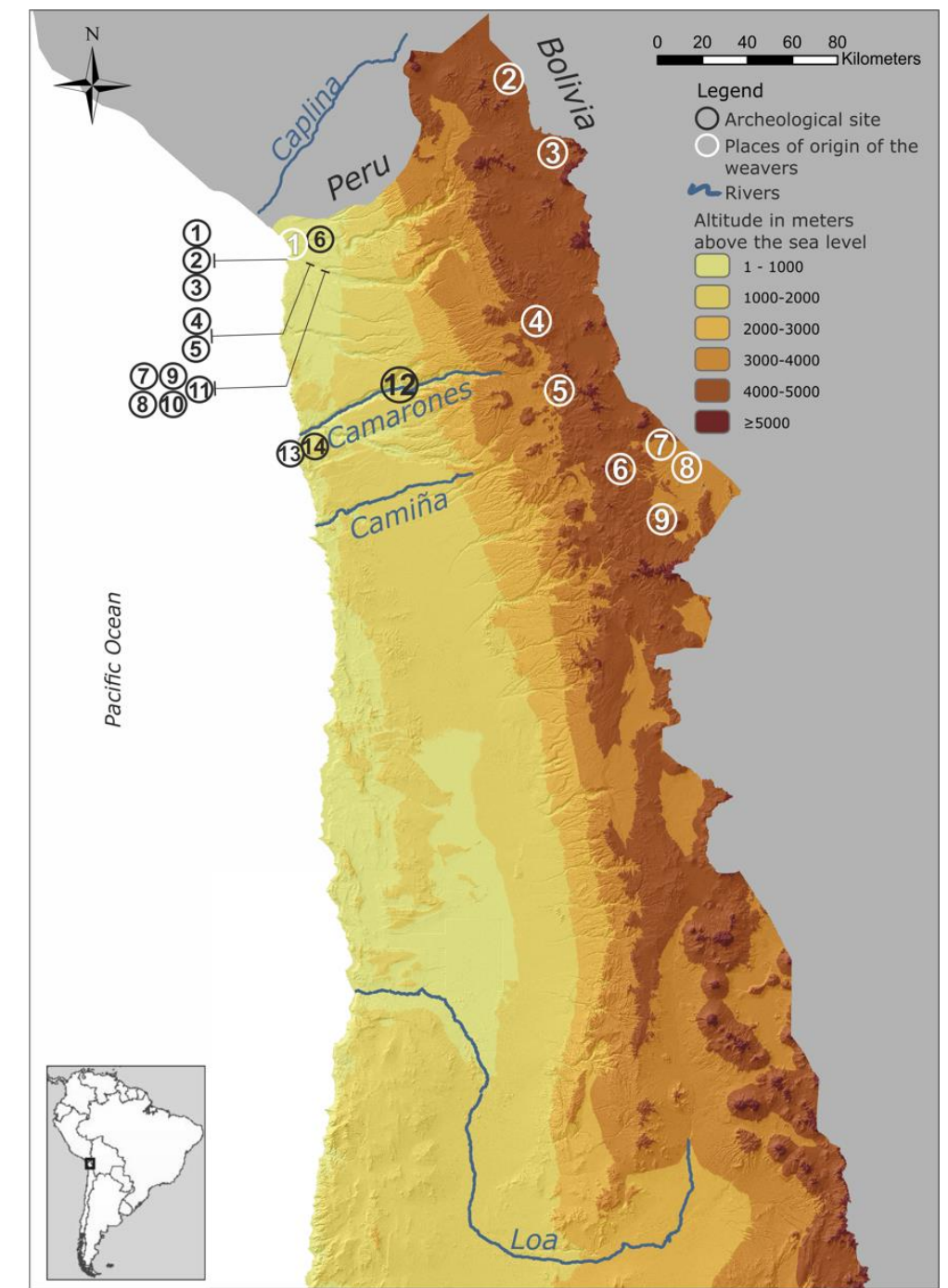

Figure 1. Northern Chile. In black, provenience of archaeological collections, most of which are from cemeteries: (1) Playa Miller; (2) Los Gentiles; (3) Playa Los Gringos; (4) Azapa 15 (AZ-15); (5) AZ-14; (6) Lluta-54; (7) AZ-140; (8) AZ-75; (9) AZ11 or San Lorenzo settlement; (10) AZ-8; (11) AZ-6; (12) Huancarane settlement; (13) Camarones-8 (Cam-8); (14) Cam-9. In white, places of origin of the weavers interviewed and locations where ethnoarchaeological documentation took place: (1) Arica; (2) Guacollo; (3) Caquena; (4) Itiza; (5) Mulluri; (6) Mauque; (7) Central Citani; (8) Escapiña; (9) Ancuaque. Map by Adrián Oyaneder.

Theory and Methods: 
In this study, textile production is understood as a social act, emphasizing its technological aspects, because in loom weaving practically all the characteristics of the pieces or objects produced are based on technical decisions and because the technical attributes carry information about ways of doing or mental representations, sensitive to variation over time and space. ${ }^{5}$ The concept of chaîne opératoire ${ }^{6}$ was employed, due to its capability to organize the extensive sequence of textile production into stages, which become manageable units of analysis.

Using these conceptual guidelines, we carried out ethnoarchaeological documentation of the production sequence developed today by Aymara weavers of northern Chile. Although it is understood that contemporary weavers are not necessarily the direct descendants of their prehispanic counterparts, they do share the same technical practice, and as a consequence, the knowledge base that sustains it. Likewise, we recognize the transformations experienced by the Andean population from the time of the conquest until today. Nonetheless, for an anthropological reflection on technology, traditional societies like those of prehispanic times and those of the present are not radically different, because a large part of their technological knowledge is based on nonverbal cognition and because every society is in a process of change, being created and recreated by its actors. ${ }^{7}$

The ethnoarchaeological documentation was created with an analytic focus, ${ }^{8}$ with the purpose of generating an array of material indicators that could be compared with the archaeological record. In that sense, we sought to articulate contemporary textile practices, considered a non-material heritage of the Andean communities with the heritage represented by the archaeological material record, which in turn helped us to consider elusive non-material aspects of the past that archaeology aspires to access by means of the study of material culture.

Prior to creating a record of technical practices, we carried out in-depth interviews of a group of weavers who come from different parts of the Andean highlands or altiplano, born outside the urban areas (Figure 1). The weavers with whom we worked to document the production sequence spent their childhood, adolescence and early adulthood in rural contexts, immersed in an Aymara speaking environment, from their early days familiarized and trained in herding and textile making activities. In that context, technical knowledge was transmitted to them through experience, visual and spatial perception and analogic reasoning, that is to say they learned by watching and by doing, with little verbal instruction. ${ }^{9}$ Generally, it was their mothers, grandmothers and/or aunts who transmitted to them knowledge of textiles. As in other Andean regions, ${ }^{10}$ this process begins early as children help clean the fleece, make the spindle or puska

\footnotetext{
${ }^{5}$ Pierre Lemonnier, Elements for an anthropology of technology. (University of Michigan, Ann Arbor, 1992).

${ }^{6}$ Marie Soressi and Jean-Michel Geneste, "History and Efficacy of the Chaîne Opératoire Approach to Lithic Analysis: Studying Techniques to Reveal Past Societies in an Evolutionary Perspective. PaleoAnthropology (Special Issue: Reduction Sequence, Chaîne Opératoire, and Other Methods: The Epistemologies of Different Approaches to Lithic Analysis, 2011), 334-350.

${ }^{7}$ Brian Pfaffenberger, "Social anthropology of technology,".Annual Review in Anthropology 21 (1992), $491-516$.

${ }^{8}$ Gustavo Politis, “Acerca de la Etnoarqueología en América del Sur.” Horizontes Antropológicos. Porto Alegre, Ano 8 (18) (2002), “Tendencias de la etnoarqueología en América Latina.” In G. Politis and R. Peretti, eds. Teoría Arqueológica en América del Sur (INCUAPA, Olavarría, 2002), 61-91.

${ }^{9}$ Lemonnier, 1992; Pfaffenberger, 1992.

${ }^{10}$ Among others, Edward M. Franquemont, Christine Franquemont and Billie Jean Isbell, “Awaq Ñawin: el ojo del tejedor. La práctica de la cultura en el tejido.” Revista Andina 19 (1994), 47-80 and Denise Y. Arnold and Elvira
} 
twirl, work on spinning and plying, and then go on to experiment with making pieces such as narrow ribbons, bands or blankets of different technical complexity. During the learning process, they master how to make particular garments, with their consequent differences in format and, therefore, the use of different looms. They also acquire skills in incorporating decorative or representational techniques, in order to create bands with motifs or basic patterns, saldas, which through exercises in abstraction, symmetry and association can be made increasingly complex.

Once married, they wove and used all the garments of domestic and ritual use that their new family required, and in accord with their obligations, they passed on their textile knowledge to at least their elder daughters. The creation of these textiles involved carrying out a production sequence that, as we were able to corroborate, had similarities with those of the past and of the present on the level of its stages, actions, technical solutions and recurring tools, which implies a technical knowledge shared between people of prehistoric times and the current day. This persistence is testimony to its effectiveness for reproducing the cultural value which textile practice had and continues to have for Andean society.

Moreover, apart from their raw materials, the objects used in textile production have a clear similarity to their known pre-Hispanic counterparts, in particular those related to the main transformations of materials, such as the spindle and whorl or puska used in spinning, the looms, the vichuña or weaving picks, needles and weaving swords (Figure 2). These may have suffered few changes over time because their function demands specific and fixed characteristics, except in the case of substantial innovations in textile form.

Among the transformations in textile practice over the last three decades are the adoption of the pedal loom, like that used since the conquest by men to create their clothing. This change in one tool also involved alteration in spinning techniques and in weaving in general, since today production has reoriented to the market and to the client. As a consequence, many traditional textiles are no longer in use nor are they produced on a regular basis, but instead are created only upon request for use in ceremonies, in carnaval festivities or as a gift to daughters and sons. This has also led to replacement of traditional types of textiles by their industrial counterparts, such that the handwoven artifact is preserved as a memento or an inheritance. Although this was initially discouraging, observing a technological change in real time is also fascinating from an archaeological perspective on the present, due to the dynamic nature of the process of change and technical transformation, while at the same time it provides a reflexive model through which to observe technological change in prehistory.

Espejo, Ciencia de las Mujeres. Experiencias en la cadena textil desde los ayllus de Challapata. ILCA (2010) and The Andean Science of Weaving: Structures and Techniques of Warp-faced Weaves. Thames and Hudson (2015). 

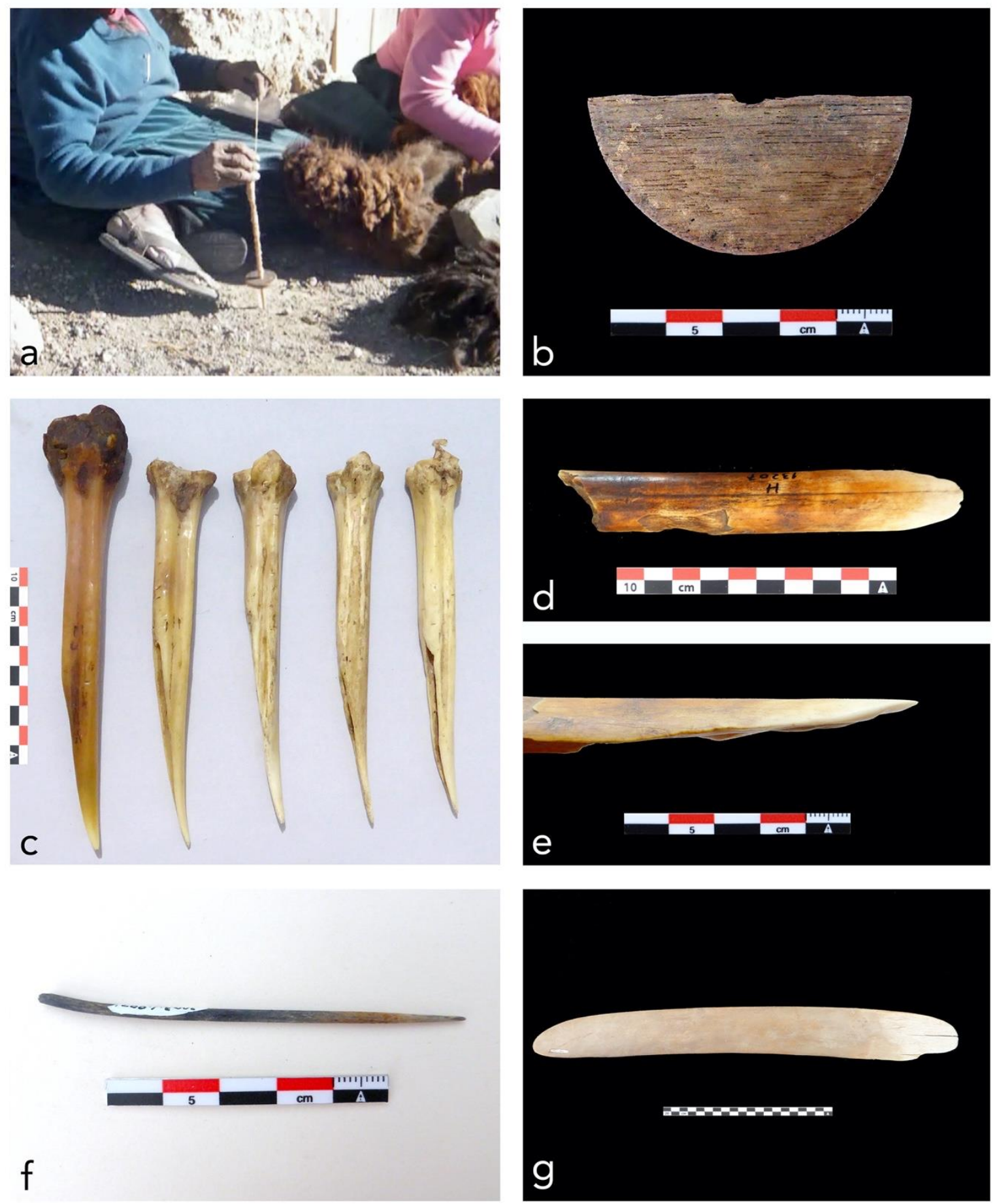

Figure 2. (a) Modern spindle or puska; (b) Archaeological broken wooden whorl (2003.1.1013); (c) Modern weaving picks or vichuña; (d) Archaeological broken weaving instrument, possibly part of a vichuña (2003.1.969); (e) Sagital view of its active edge; (f) Archaeological cactus thorn needle without (2003.1.997); (g) Archaeological weaving sword or tujlla (2003.1.960). All archaeological materials are from Huancarane site and belong to the Collection of the National Museum of Natural History, Chile. Photos (a) and (c) B. C. Cases; Photos (b), (d), (e), (f) and $(g)$ D. Valenzuela. 
Ethnoarchaeological documentation of the production process:

To create an ethnoarchaeological description, we accompanied and colaborated with the weaver Celinda Castro in the shearing process, in the locale of Itiza, district of Putre (see Fig. 1); during the process of warping a talega bag, in Central Citani, district of Colchane; preparation of the loom, start of the weaving process and during the completion of weaving a chuspa bag that was ordered from her for use in a ceremony. The last two activities took place in the city of Arica. In that city we documented the finishing processes with Luzmira Mamani, the process of fleece cleaning and selection with Felipa Condori and that of spinning and plying with Felipa, Edalia Lázaro and Luzmira.

The resulting documentation considered each stage of the production process and its material outcomes (Figure 3), all the aspects that have consequences affecting the textile objects of the past and present, as well as the contexts in which these are used and discarded. We did not consider dyeing, as it constitutes another complete and complex production process.

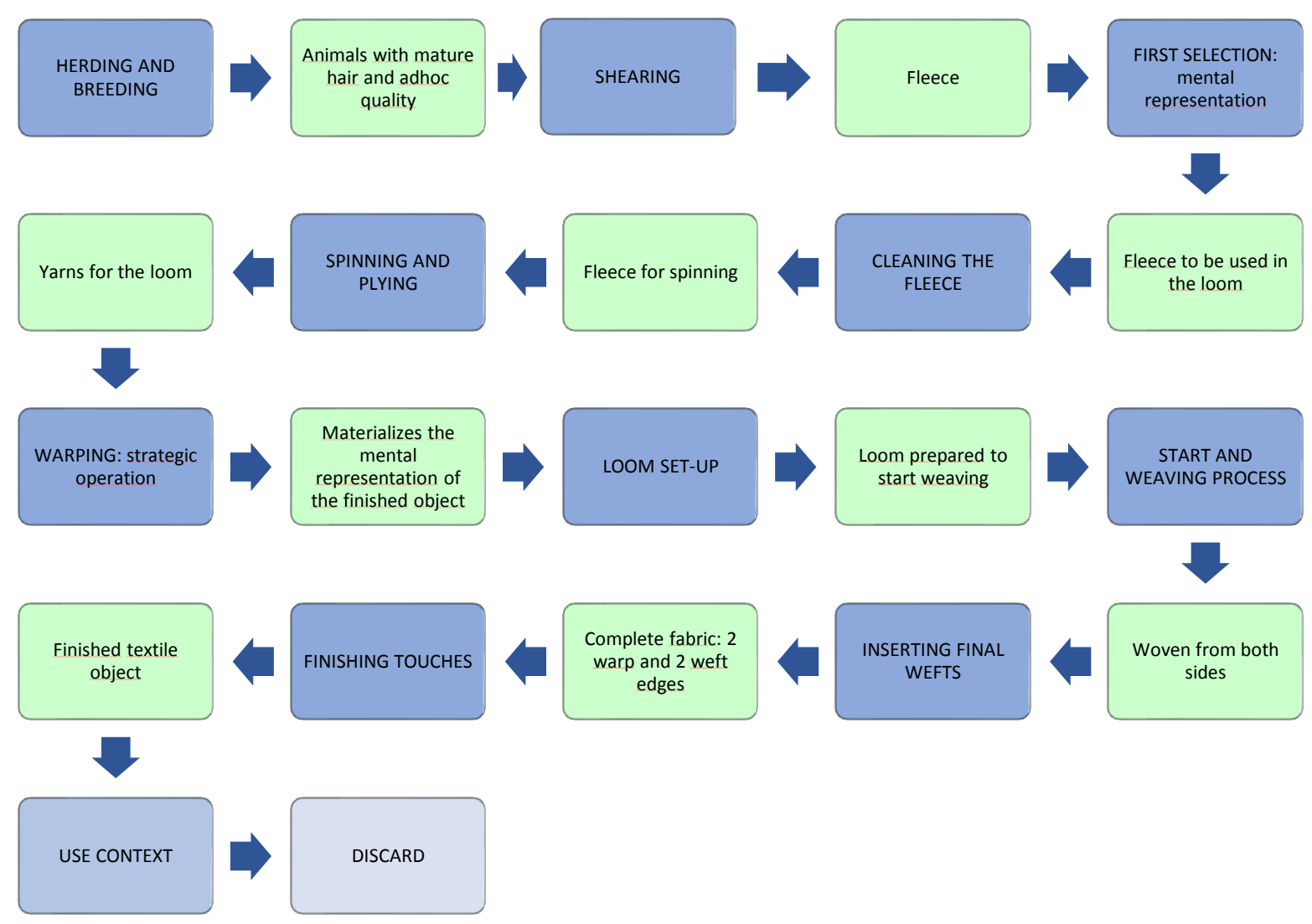

Figure 3. Schematic of the stages of the textile technical process, in capital letters on blue, and their outcomes, in small letters on green.

The information resulting from this documentation was systematized in order to orient the search for evidence of prehispanic textile production - what to look for and where to look - by relating the material aspects to immaterial dimensions, indicated as follows: 
Material aspects:

- Where it takes place and if there are different areas of activity, the spatial relationship between them.

- Tools in use.

- Waste from the activity and its location.

Inmaterial aspects:

- Time of day and/or season it takes place in, duration and interruptions if any. Approximate times were considered, since actions are usually overlapping.

- Who participates (number of people, gender, age and relationship between participants) and how they organize themselves in each task.

- What each action consists of from a body/manual point of view and whether they are repetitive or not.

Subsequently, this information was organized based on non-mobile and mobile indicators of each stage in order to generate an analytic methodology (Table 1). The mobile indicators include the textile materials employed, for example production in camelid fiber (llama, alpaca, or vicuña) using textile processes and techniques, that carried out using other raw materials which are important during each stage. Regarding the non-mobile indicators, these correspond to the specific places where each stage is carried out and their geographic context.

\begin{tabular}{|l|l|l|l|l|}
\hline \multicolumn{2}{|l|}{} & \multicolumn{2}{l|}{$\begin{array}{l}\text { MOBILE } \\
\text { INDICATORS }\end{array}$} & \multicolumn{2}{l|}{$\begin{array}{l}\text { NON-MOBILE } \\
\text { INDICATORS }\end{array}$} \\
\hline $\begin{array}{l}\text { PRODUCTIVE } \\
\text { STAGE }\end{array}$ & $\begin{array}{l}\text { TEXTILE } \\
\text { MATERIAL }\end{array}$ & $\begin{array}{l}\text { OTHER RAW } \\
\text { MATERIALS }\end{array}$ & $\begin{array}{l}\text { SITES- } \\
\text { SPECIFIC } \\
\text { PLACES }\end{array}$ & LOCATION \\
\hline $\begin{array}{l}\text { From herding to } \\
\text { finished textile }\end{array}$ & $\begin{array}{l}\text { Raw materials, } \\
\text { tools and objects } \\
\text { in fiber, waste, } \\
\text { residues and } \\
\text { resulting } \\
\text { products }\end{array}$ & $\begin{array}{l}\text { Tools or utensils } \\
\text { made of bone, } \\
\text { stone, wood, } \\
\text { metal, etc., used } \\
\text { in different stages } \\
\text { of an operation }\end{array}$ & $\begin{array}{l}\text { Sites, residential } \\
\text { areas, corrals, } \\
\text { dump areas, } \\
\text { interior-exterior } \\
\text { of dwellings }\end{array}$ & $\begin{array}{l}\text { Geographic } \\
\text { location }\end{array}$ \\
\hline
\end{tabular}

Table 1. Summary of the analytical method: set of factors to be considered.

Testing the Analytic Method:

The set of indicators obtained through the ethnoarchaeological research experience was tested on the Huancarane settlement textile assemblage, located in the middle of Camarones Valley, Northern Chile and dated circa 1400-1450 AD (See Fig. 1). The site was excavated in the mid 1970s by Hans Niemeyer and Virgilio Schiapaccasse. ${ }^{11}$ Specifically, the textile material recovered comes from five habitation structures and three depressions used for storage of foodstuffs and to deposit waste. The authors identified raw materials and distinguished cordage and textiles, indicating some technical differences within each category. They also described

\footnotetext{
${ }^{11}$ Niemeyer and Schiapaccasse 1981. The excavated artifacts are part of the collection of the Museo Nacional de Historia Natural in Santiago, Chile.
} 
spindle whorls and a weaving sword that must have been used to create textiles (see Fig. $2 \mathrm{~b}$ and $2 \mathrm{~g})$.

The 493 textile items -consisting of the remains of fleece, yarns, cordage and textile fragmentsas well as the textile production tools, were organized according to the analytic methodology summarized above. As a result, it was possible to distinguish two production processes: one leading to loom weaving, with probable feminine associations and the other oriented towards creating cordage, presumably a masculine activity (Figure 4).

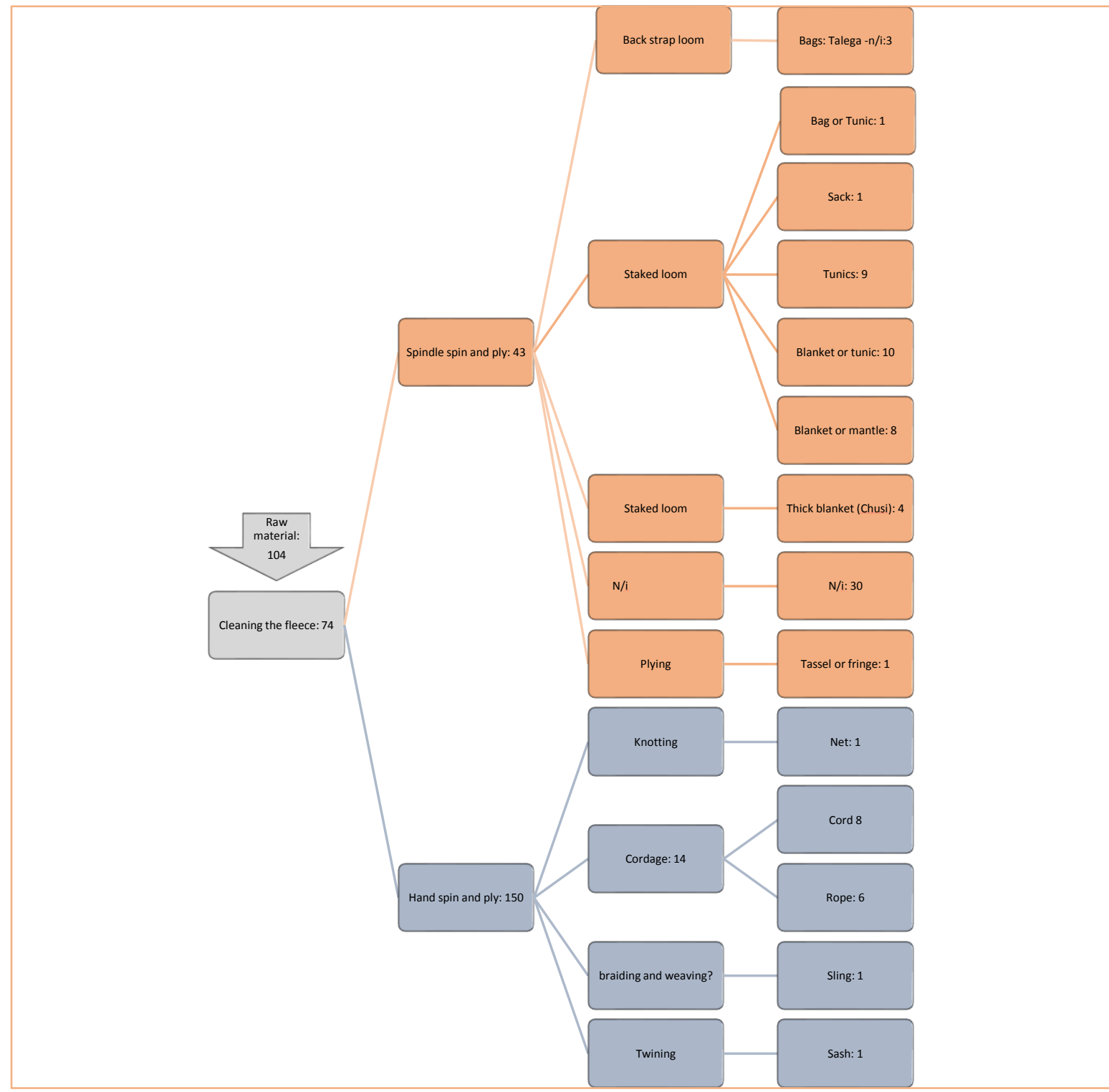

Figure 4. Summary of the stages of the production processes detected in Huancarane.

Evidence for the process of cleaning the fleece consisted of remnants of fleece containing vegetal remains and clean raw fiber. This activity is carried out after first separating out fleece of a quality suitable for creating yarn for loom weaving, from that suitable to be used for cordage and that which cannot be used for textile purposes, to be later used for fuel. In the case of the 
Huancarane material, it was not possible to make the distinction based on fiber quality, so the production processes were differentiated based on the evidence for spinning practices. To this end, evidence was found of spinning and plying processes using the puska or spindle with whorl, in the form of singles yarns and two-ply yarns, as well as spindle whorls of both wood and ceramic types (Fig. 2b).

Although the woven material consisted basically of fragments, some of these very worn and with evidence of repair, by drawing upon reference collections of textiles from different locations in the far north of Chile (Fig. 1), the majority could be assigned to particular textile forms. Based on this process and/or the dimensions of certain fragments, it was possible to infer the type of loom used. For example, some fragments corresponding to talega bags, used to transport and store small amounts of foodstuffs, would have been created on a backstrap loom. On the other hand, larger-scale pieces such as tunics, sacks, mantles or blankets would have required the use of a staked loom. We should note that in the case of the heavy mantles, these would have constituted a separate process from the phase of spinning and plying the yarn, as they required much thicker yarns, which thus would have been spun specifically for their creation. Judging by finds of fragmentary vichuñas and a weaving sword or tujlla, used to keep the shed open during insertion of the weft (see Fig. 2d, e and g), we propose that the weaving process may have been carried out in the settlement of Huancarane. Likewise, finds with cactus thorn needles indicate that actions such as insertion of the final wefts to complete a weaving, creation of the edge finishes, and repairs were also carried out at the site (Fig. 2f). In reference to the latter, the presence of wear and repairs in the cloth fragments documents the intense use of these textiles previous to their discard.

Similarly, the evidence for a production process with masculine associations consists of the characteristics of manual spinning or mismir, present in the yarns themselves, as well as a piece of wood that was used to wind a thick and irregular yarn. These yarns would have been used to create primarily utilitarian objects such as nets, cordage, slings and bands.

From a cultural perspective, the textile remains obtained through these operational chains are related to their counterparts in adjacent regions, particularly of their coastal areas. On the one hand, the textiles are linked to those of the Arica Culture that extends between the coast and low valleys from the Caplina river in the extreme south of Peru to the Camarones Valley (Fig. 1). ${ }^{12}$ On the other hand, the material is also related to the Pica-Tarapacá Complex, which extends between the coast and high ravines from the Camiña to the Loa rivers (Fig. 1). ${ }^{13}$ With this data, the Camarones valley seems to be an area of frontier or social articulation between both cultural entities, towards the end of the Late Intermediate Period (circa 900-1400 AD) and even contemporaneously with the Inca presence in the area, according to the dating of the site.

\footnotetext{
${ }^{12}$ Iván Muñoz, Carolina Agüero and Daniela Valenzuela "Poblaciones Prehispánicas de los Valles Occidentales del norte de Chile: desde el Período Formativo al Intermedio Tardío (ca. 10.000 años a.C. a 1.400 años d.C.)”. In F. Falabella, M. Uribe, L.Sanhueza, C. Aldunate y J. Hidalgo, eds. Prehistoria en Chile. Desde susprimeros habitantes hasta los Incas (Editorial Universitaria and Sociedad Chilena de Arqueología, Santiago, 2016), 181-237; Carolina Agüero, Vestuario y sociedad andina. Desarrollo del Complejo Pica-Tarapacá (800-1400 DC) (Ocho Libros Editores, Santiago, 2015).

${ }^{13}$ Muñoz, Agüero and Valenzuela 2016; Agüero 2015.
} 
Final words:

The application of this analytic method to the textiles of the Huancarane settlement has permitted the recognition of on-site textile production, as shown in four stages of the loom woven manufacturing process, possibly performed by women: cleaning the fiber, spinning, weaving, finishing as well as repairs and likewise a masculine manufacturing process using hand-spun yarns, mismir. Based on the archaeological provenience of the textile material, we can consider that the production scale was domestic. The products were fabrics for everyday use: as clothing, for warmth, for carrying, containing and transporting food and for other practical uses such as cords, ropes, slings and nets. To a much lesser extent, a few possible ritual textiles were identified. This suggests that textiles of daily use were different from the ceremonial domain, of which the mortuary ritual forms a part. In that sense, these results invite us to develop comparisons among the textiles found in habitational sites, in some fashion independent from those found in funerary sites.

This analytic model, without doubt still to be perfected, can constitute a road map for approaching pre-Hispanic textile production based on the residues, textiles and evidence from other raw materials found in the places where textiles were produced and used. Also, it has provided a useful focus for the analysis of assemblages of fleece and yarns of the late Pleistocene in northern Chile (circa $11000 \mathrm{BP}) .{ }^{14}$ In an ongoing research project, this methodology is to be extended to other textile assemblages from habitation sites in the region, which will allow us to broaden its application and generate a body of information that can help build understanding of pre-Hispanic textile production.

\section{Acknowledgements}

To Dr. Ann Peters for organizing Session 3A "Dialogues between archaeological, historical and contemporary textiles in the Andes/ Diálogos entre textiles arqueológicos, históricos y contemporáneos" at TSA's $17^{\text {th }}$ Biennial Symposium, for her constant support in developing the presentation, writing and translation of this text and for sustaining dialogue about textiles in this strange time. To the weavers: Celinda Castro, Isabel Choque y Luzmira Mamani, together with Felipa Condori, Edalia Lázaro, Silvia Mendoza, Ángela Mamani, María Choque, Teresa Mamani, Rosana Castro, Honoria Castro, Yéssica Mamani, Mónica Mamani, Delia Castro, Susana Fernández, Lidia Amaru, Valentina Inquiltupa, Teresa Ticuna, Patricia Huanca, Elba Mamani, Flora Vilchez, Claudia Mamani, Celia Challapa, Gertrudis Mamani, Liucaria Challapa, Felisa Castro, Basilia Castro, María Challapa, Adelina Mamani, Soria Mamani, Juana Mamani, Isabel Challapa, Flora García, Erika Mamani, Patricia Flores. To Ceferino Choque. To the program in Development of Advanced Human Resources of Conicyt (Postgraduate Fellowship for Studies in Chile D-21080465), Fondecyt Project 1201687 and 1150916, Project PCI2015008, PIA/ANILLO SOC 1405, UTA Mayor Project 3738-19; to the team of the Anthropology Section from the Museo Nacional de Historia Natural, Chile, for authorizing the study and publication of photographs of the collection of Huancarane; to the Museo Arqueológico San

\footnotetext{
${ }^{14}$ Calogero M. Santoro, Eugenia M. Gayo, José M. Capriles, Marcelo M. Rivadeneira, Katherine A. Herrera, Valentina Mandakovic, Mónica Rallo, Jason A. Rech, Bárbara Cases, Luis Briones, Laura Olguín, Daniela Valenzuela, Luis A. Borrero, Paula C. Ugalde, F. Rothhammer, Claudio Latorre, and Paul Szpak. "From the Pacific to the Tropical Forests: Networks of Social Interaction in the Atacama Desert, Late in the Pleistocene." Chungara, Revista de Antropología Chilena 51(1) (2019), 5-25.
} 
Miguel de Azapa- Universidad de Tarapacá for authorizing the study of reference collections of the Arica Culture; to Dr. Daniela Valenzuela, for her help in diagramming Figure 2 and to colleagues Rolando Ajata and Adrián Oyaneder for providing spatial information and the preparation of Figure 1, respectively.

Bibliography

Agüero, Carolina. Vestuario y sociedad andina. Desarrollo del Complejo Pica-Tarapacá (8001400 DC). Santiago: Ocho Libros Editores, 2015.

Agüero, Caroline and Donley-Zori. "Otro quipu encontrado al sur de Arica," Boletín de la Sociedad Chilena de Arqueología 40 (2007), 21-28.

Agüero, Carolina, Mauricio Uribe, Patricia Ayala and Bárbara Cases. "Una aproximación arqueológica a la etnicidad y el rol de los textiles en la construcción de la identidad cultural en los cementerios de Quillagua (Norte de Chile)," Gaceta Arqueológica Andina 25 (1999), 167197.

Arnold, Denise Y. and Elvira Espejo. Ciencia de las Mujeres. Experiencias en la cadena textil desde los ayllus de Challapata. ILCA, 2010.

Arnold, Denise Y. and Elvira Espejo. The Andean Science of Weaving: Structures and Techniques of Warp-faced Weaves. London: Thames and Hudson, 2015.

Cases, Barbara. Etnoarqueología y Tecnología de las Bolsas a la Producción Textil Prehispánica. Un caso de estudio en Huancarane (Período Intermedio Tardío, Valle de Camarones). PhD dissertation, Departamento de Antropología de la Universidad de Tarapacá e Instituto de Investigaciones Arqueológicas, Universidad Católica del Norte, Chile, 2017.

Cases, Bárbara. “Las bolsas de Quillagua y su relación con el tráfico de caravanas," Werken 4 (2003), 5-24.

Franquemont, Edward M. Christine Franquemont and Billie Jean Isbell. "Awaq Nawin: el ojo del tejedor. La práctica de la cultura en el tejido," Revista Andina 19 (1994), 47-80.

Horta, Helena. El señorío Arica y Los Reinos Altiplánicos (1000-1450 DC). Complementariedad ecológica y multietnicidad durante los siglos pre-conquista en el norte de Chile. Ocho Libros Editores, 2015.

Horta, Helena and Carolina Agüero. "Definición de chuspa: textil de uso ritual durante el Período Intermedio Tardío, en la zona arqueológica de Arica," Actas del XIV Congreso Nacional de Arqueología Chilena. Copiapó: Museo Regional de Atacama, 2000.

Horta, Helena and Carolina Agüero. "Estilo, iconografía y función de las inkuñas prehispánicas del norte de Chile durante el Período Intermedio Tardío (1.000-1.470 D.C.)," Chungara, Revista de Antropología Chilena 41(2) (2009), 183-227. 
Lemonnier, Pierre. Elements for an anthropology of technology. Ann Arbor: University of Michigan, 1992.

Muñoz, Iván. "Ocupación del espacio doméstico y áreas de actividad generadas en el asentamiento prehispánico de San Lorenzo," Diálogo Andino 24 (2004), 53-97.

Muñoz, Iván, Carolina Agüero and Daniela Valenzuela. "Poblaciones Prehispánicas de los Valles Occidentales del norte de Chile: desde el Período Formativo al Intermedio Tardío (ca. 10.000 años a.C. a 1.400 años d.C.)," F. Falabella, M. Uribe, L.Sanhueza, C. Aldunate y J. Hidalgo, eds. Prehistoria en Chile. Desde susprimeros habitantes hasta los Incas. Santiago: Editorial Universitaria and Sociedad Chilena de Arqueología, 2016, 181-237.

Niemeyer, Hans and Virgilio Schiapaccasse. "Aportes al conocimiento del Período Tardío del extremo norte de Chile: Análisis del sector de Huancarane del valle de Camarones." Chungara 7 (1981), 3-103.

Pfaffenberger, Brian. "Social anthropology of technology," Annual Review in Anthropology 21 (1992), 491-516.

Politis, Gustavo. "Acerca de la Etnoarqueología en América del Sur," Horizontes Antropológicos. Porto Alegre, Ano 8 (18) (2002).

Politis, Gustavo. "Tendencias de la etnoarqueología en América Latina," G. Politis and R. Peretti, eds. Teoría Arqueológica en América del Sur Olavarría: INCUAPA, 2002, 61-91.

Santoro, Calogero M. Late prehistoric regional interaction and social change in a coastal valley of northern Chile. Ph.D. Dissertation, Department of Anthropology, University of Pittsburgh, Pittsburgh (1995).

Santoro, Calogero M. Eugenia, M. Gayo, José M. Capriles, Marcelo M. Rivadeneira, Katherine A. Herrera, Valentina Mandakovic, Mónica Rallo, Jason A. Rech, Bárbara Cases, Luis Briones, Laura Olguín, Daniela Valenzuela, Luis A. Borrero, Paula C. Ugalde, F. Rothhammer, Claudio Latorre, and Paul Szpak. "From the Pacific to the Tropical Forests: Networks of Social Interaction in the Atacama Desert, Late in the Pleistocene," Chungara, Revista de Antropología Chilena 51(1) (2019), 5-25.

Soressi, Marie and Jean-Michel Geneste. "History and Efficacy of the Chaîne Opératoire Approach to Lithic Analysis: Studying Techniques to Reveal Past Societies in an Evolutionary Perspective," PaleoAnthropology (Special Issue: Reduction Sequence, Chaîne Opératoire, and Other Methods: The Epistemologies of Different Approaches to Lithic Analysis, 2011), 334-350. 